\title{
Pengaruh Bauran Pemasaran Dan Kualitas Pelayanan Terhadap Keputusan Pembelian Pada PT Indomarco Pratama Denpasar Bali
}

\author{
Gde Indra Surya Diputra ${ }^{(1)}$ \\ Gede Agus Dian Maha Yoga ${ }^{(2)}$ \\ (1)(2)Universitas Hindu Indonesia, Denpasar, Bali, Indonesia \\ Email : gdeindra@gmail.com

\begin{tabular}{|l|l|l|}
\hline Diterima: 24 Juni 2020 & Direvisi: 5 Agustus 2020 & Disetujui: 10 Agustus 2020 \\
\hline
\end{tabular}

\begin{abstract}
This study discusses analyzing the marketing mix and service quality of purchasing decisions at PT. Indomarco Pratama Denpasar Bali. This research method is quantitative descriptive using questionnaires as a method of data collection and multiple linear regression analysis using SPSS. The results showed that the promotional mix involved a partial purchase decision of consumers at PT Indomarco Pratama Denpasar Bali by $0.002<0.05$, with a dominant product, price, and promotion indicators, starting to look for indicators of other places, people, physical evidence, processes. PT. Indomarco Pratama Denpasar Bali is $0.003<0.05$, with dominant Empathy, Reliability, Responsiveness indicators, then tangibles indicators, guarantees accepted. Simultaneously the marketing mix and service quality influence the purchasing decision of 0,000 <0.05. These results also answer the three hypotheses of this study. The results show that the marketing mix and the quality of services offered are positive and significant for purchasing decisions. The results have the meaning of increasing marketing mix and service quality, so the purchasing decisions at PT Indomarco Pratama Denpasar Bali will also increase.
\end{abstract}

Keywords : Price, Marketing, Service Quality, Purchasing Decisions

\section{Pendahuluan}

Era pasar bebas di kawasan Asia telah dimulai dengan AFTA 2003, hal ini membawa dunia ritel Indonesia pada realitas Global Retailing yang mau tidak mau harus diterima. Era ini ditandai dengan masuk dan semakin berkembangnya peritel global. Kelompok industri ritel saat ini banyak dipegang oleh peritel asing, seperti Carrefour milik Prancis, Sogo milik 2 Jepang, Makro sekarang menjadi Lotte Mart milik Belanda, dan juga Tesco dan Bigzy milik Inggris, kehadiran peritel asing di Indonesia juga turut menyemarakkan persaingan industri Indonesia. Indonesia menjadi sasaran empuk para peritel dunia dengan pasar sebesar 230 juta jiwa. Pasar yang besar ini menjadikan Indonesia sebagai pasar para peritel global yang paling atraktif di kawasan Asia. 
Bentuk usaha ritel yang mengalami perkembangan cukup pesat adalah minimarket. Dewasa ini bermunculan minimarket dengan berbagai fasilitas yang semakin lengkap. Pada dasarnya keberhasilan usaha ritel terletak pada penyediaan produk sehari-hari, baik secara kualitas maupun kuantitas serta harga yang terjangkau terutama bagi masyarakat berpenghasilan sedang. Lembaga survei AC Nielsen menyebutkan bahwa tingkat pertumbuhan ritel secara umum di Indonesia sebesar 15\% di tahun 2009. Sementara secara lebih spesifik dinyatakan bahwa jumlah pasar modern seperti hypermarket, supermarket dan minimarket di Indonesia mengalami peningkatan sebesar 34,4\% di tahun 2009, dengan hypermarket sebagai yang tertinggi omsetnya sebesar 41,7\% atau Rp.23,10 trilyun dari keseluruhan omset penjualan pasar modern. Selain itu, hingga tahun 2005, market share Indomaret mencapai 35\% secara nasional (Asosiasi Pengusaha Ritel Indonesia, 2020)

Indomaret didirikan oleh PT Indomarco Prismatama sejak tahun 1998, sebagai bisnis ritel berbentuk minimarket yang pertama di Indonesia. Karena 3 itu wajar bila usaha ritel milik Grup Salim ini tampil sebagai leader, dengan jumlah waralaba kurang dari 1500 unit dan omzet sebesar Rp. 8 triliun. Memilih tempat berbelanja adalah proses interaksi antara strategi pemasaran peritel dan karakteristik individual dan situasional dari pembeli menyebabkan pandangan umum tentang aktivitas yang terlibat dalam perilaku pembelian suatu produk.

Keputusan pembelian merupakan salah satu komponen utama dari perilaku konsumen yang mengarah kepada pembelian produk atau jasa. Menurut Setiadi dikutip oleh, keputusan pembelian konsumen ialah proses pengintegrasian yang mengkombinasikan pengetahuan untuk mengevaluasi dua perilaku alternatif atau lebih, dan memilih salah satu diantaranya. Hasil dari proses pengintegrasian ini ialah suatu pilihan yang sajikan secara kognitif sebagai keinginan berperilaku (Sangadji dan Sopiah, 2013:21).

Seorang konsumen sebelum memutuskan untuk membeli suatu produk, konsumen melalui beberapa tahapan terlebih dahulu misalnya pengenalan masalah, pencapaian informasi, evaluasi terhadap alternatif pembelian, keputusan pembelian dan tingkah laku setelah pembelian (Sunyoto, 2014:284). Masalah timbul dari dalam diri konsumen yang berupa kebutuhan yang digerakkan oleh rangsangan dari dalam diri konsumen itu sendiri ataupun berasal dari luar diri konsumen, setelah timbul masalah yang mendorong konsumen untuk memenuhi kebutuhannya kemudian konsumen akan mencari informasi tentang objek yang bisa memuaskan keinginannnya. Dari informasi yang diperoleh konsumen tersebut digunakan untuk memperoleh gambaran yang lebih jelas mengenai suatu produk. Selanjutnya setelah tahap 
tersebut konsumen akan menentukan merek barang yang disukainya untuk melakukan keputusan pembelian.

Harga merupakan faktor penting dalam kegiatan pemasaran. Penentuan harga pada suatu produk yang dilakukan oleh perusahaan sangat berpengaruh terhadap keputusan pembelian konsumen dikarenakan dengan tingkat harga yang telah ditetapkan oleh perusahaan dapat menjadi tolak ukur akan permintaan suatu produk. Apabila harga suatu produk lebih tinggi dari harga rata-rata produk lain maka perbedaan ini dapat mempengaruhi jumlah permintaan, sementara harga yang lebih rendah dari rata-rata dapat berdampak baik karena kecenderungan konsumen pada harga yang lebih murah dengan kualitas yang sama (Malau, 2016:25). Akan tetapi sebaliknya apabila harga terlampau murah, perusahaan sulit mendapatkan laba atau sebagian konsumen berpendapat bahwa kualitasnya buruk.

Selain harga, faktor penting yang mempengaruhi keputusan pembelian konsumen adalah produk. Produk ialah segala sesuatu yang bisa ditawarkan di pasar untuk memuaskan kebutuhan dan keinginan konsumen (Manap, 2016:255). Produk yang ditawarkan kepada konsumen harus memiliki kulitas yang baik, unik, dan penampilan yang menarik sehingga konsumen menjadi tertarik untuk membeli produk tersebut. Produk yang memiliki kualitas yang baik dapat mendorong perusahaan untuk mempertahankan usahanya dan mampu bersaing dengan pesaing lainnya. Selain harga dan produk, lokasi dan promosi juga merupakan hal yang penting dalam baruan pemasaran.

Kegiatan pemasaran yang meliputi perkembangan produk, penentuan harga, pendistribusian, dan promosi perlu dikombinasikan dengan tepat dan optoimal agar tercapai penjualan yang maksimal, yang dikenal dengan bauran pemasaran. Bauran pemasaran ini dilakukan oleh menajer pemasaran berdasarkan pasar sasaran dan penentuan posisi produk di pasar sasaran. Kombinasi yang serasi diantara variabel-variabel bauran pemasaran yang dilaksanakan dengan baik apabila setiap setiap variabel memperoleh tingkatan dan posisi yang tepat dan seimbang sesuai dengan posisi produk dan pasar sasaran.

Menurut Kotler (2000:15), bauran pemasaran adalah : "Marketing mix is the set of controllable tactical marketing tool that the firm uses to pursue it's marketing objectives in the target market". Artiya, bauran pemasaran merupakan seperangkat alat yang digunakanh perusahaan untuk mencapai tujuan dalam pasar sasaran. Menurut Zeithaml dan Binner (2000:18), bauran pemasaran adalah : "Marketing mix defined as the elements an organization control that can be used to satisfy or communicate with consumers". (bauran pemasaran didefinisikan sebagai alat kotrol organisasi yang dapat digunakan untuk memuaskan atau 
mengkomunikasikan dengan konsumen). Sedangkan menurut Keagen (1995:18), bauran pemasaran adalah: "Marketing mix is the set of tools and techniques of the product, its pricing and distribution, and its marketing communication used by an organization market its product at a profit. These element of the marketing mix are sometimes called the four P's: product, price, place, and promotion".

Bauran pemasaran merupakan gabungan dari peralatan dan tehnik produk, harga, dan distribusinya, serta komunikasi pemasarannya yang digunakan oleh suatu organisasi untuk memasarkan produknya. Kotler (2012:10) menjelaskan "pemasaran adalah suatu proses sosial dan manajerial yang didalamnya individu atau kelompok untuk mendapatkan apa yang mereka butuhkan dan inginkan dengan menciptakan, menawarkan, dan secara bebas mempertukarkan produk yang bernilai dengan pihak lain".

Keputusan pembelian seorang konsumen, selain berdsarkan bauran pemasaran juga berdasarkan kualitas pelayanan dari sebuah perusahaan. Kualitas pelayanan yang baik sangat penting bagi kemajuan dan tercapainya cita-cita sebuah perusahaan. Dengan kualitas pelayanan yang baik, akan memberikan kesan positif dari pelanggan terhadap suatu perusahaan. Kualitas pelayanan (Service Quality) adalah pandangan konsumen terhadap hasil perbandingan antara ekspektasi konsumen dengan kenyataan yang diperoleh dart pelayanan. Sedangkan kepuasan adalah persepsi pelanggan terhadap satu pengalaman layanan yang diterima (Wiratno, 1998:15)

Dalam mengidentifikasi dimensi karakteristik yang digunakan oleh para pelanggan dalam mengevaluasi kualitas pelayanan, terdiri dari lima dimensi. Kelima dimensi karakteristik kualitas pelayanan tersebut adalah Kehandalan (Reliability), Daya Tanggap (responsiveness), Jaminan (Assurance), Empathy, dan Bukti Langsung (Tangibles). Kualitas pelayanan menjadi salah satu ukuran atas keberhasilan dalam memberikan jaminan atas kepuasan bagi konsumen, melalui kualitas pelayanan seorang konsumen dapat memberikan penilaian secara obyektif dalam usaha menciptakan kepuasan konsumen yang pada akhirnya mempengaruhi keputusan pembelian (Yamit, 2005:10).

Berdasarkan uraian diatas, maka peneliti tertarik untuk membahasa tentang pengaruh bauran pemasaran dan kualitas pelayanan terhadap keputusan pembelian pada pada PT Indomarco Pratama Denpasar Bali yang berada di Jl. Pulau Kawe, Dauh Puri Klod, Kota Denpasar. 


\section{Telaah Literatur dan Kajian Pustaka}

\section{Bauran Pemasaran}

Bauran pemasaran adalah alat-alat pemasaran yang terdiri dari tujuh elemen yaitu product, price, promotion, place, people, physical evidance dan process yang semua variabelvaribelnya dapat dikendalikan oleh suatu organisasi untuk mencapai keunggulan bersaing (competitive advantage). Organisasi yang bergerak dibidang jasa (service) menggunakan bauran pemasaran jasa ini untuk membantu strategi mereka dalam mencapai nilai jasa/ konsumen yang tinggi menurut konsumen (customer value) yang akhirnya menentukan posisi persaingan (competitive position) pada pasar sasaranya. (Haksever, et. al, 2000;131).

1. Product (Produk), menurut Kotler (2012:9) merupakan segala sesuatu yang dapat ditawarkan produsen untuk diperhatikan, diminta, dicari, dibeli, digunakan, atau dikonsumsi pasar sebagai pemenuhan kebutuhan atau keinginan pasar yang bersangkutan.

2. Price (Harga), menurut Kotler (2012:302), harga adalah sejumlah uang yang dibebankan untuk sebuah produk atau jasa. Harga adalah jumlah dari nilai yang ditukar konsumen atas manfaat-manfaat karena memiliki atau menggunakan produk/jasa

3. Promotion (Promosi), merupakan salah satu faktor penentu keberhasilan suatu program pemasaran. Tjiptono (2014:22) mengungkapkan bahwa promosi adalah semua kegiatan yang dimaksudkan untuk menyampaikan atau mengkomunikasikan suatu produk kepada pasar sasaran, untuk memberi informasi tentang keistimewaan, kegunaan dan yang paling penting adalah tentang keberadaannya, untuk mengubah sikap ataupun untuk mendorong orangorang supaya bertindak.

4. Place (Lokasi), merupakan variabel bauran pemasaran yang berupa lokasi. Place ini berkenaan dengan upaya penyampaian produk yang tepat ke tempat pasar target.

5. People (Orang), menurut Zeithaml and Bitner (2000:19) merupakan semua pelaku yang memainkan peranan dalam penyajian jasa sehingga dapat mempengaruhi persepsi pembeli.

6. Physical Evidence (Sarana Fisik), merupakan salah satu variable bauran pemasaran yang berupa tampilan fisik dari perusahaan yang menunjukkan tempat dimana jasa diciptakan dan dimana pemberi jasa dan pelanggan berinteraksi. Contoh physical evidence: penampilan gedung, penampilan toko, penampilan brosur, interior toko, fasilitas toko, musik sebagai latar belakang transaksi dan lain lain.

7. Process (Proses ), menurut Payne (2000:168) diartikan sebagai tindakan menciptakan dan memberikan jasa pada pelanggan dan merupakan faktor penting dalam bauran pemasaran jasa, karena pelanggan jasa akan merasakan sistem pemberian jasa tersebut sebagai bagian 
dari jasa itu sendiri. Proses adalah semua prosedur actual, mekanisme, dan aliran aktivitas yang digunakan untuk menyampaikan jasa.

Pemasaran adalah proses sosial dan manajerial di mana individu dan kelompok mendapatkan apa yang mereka butuhkan dan inginkan melalui penciptaan dan pertukaran produk dan nilai satu sama lain" (Tjiptono, 2014:3).

Beberapa penelitian terdahulu menunjukkan bahwa bauran pemasaran berpengaruh secara signifikan terhadap keputusan pembelian, diantaranya penelitian Alfiani (2014) menunjukkan bahwa bauran pemasaran berpengaruh terhadap keputusan pembelian produk. Pertiwi (2016) Bauran Pemasaran secara bersama-sama dan parsial berpengaruh terhadap Keputusan Pembelian pada konsumen. Penelitian Hasrina (2017) menunjukkan bahwa bauran pemasaran (Produk, Harga, Distribusi dan Promosi) secara bersama-sama berpengaruh positif dan signifikan terhadap keputusan pembelian.

\section{Kualitas Pelayanan}

Tjiptono (2014:59) menyatakan bahwa kualitas pelayanan adalah tingkat keunggulan yang diharapkan dan pengendalian atas tingkat keunggulan tersebut untuk memenuhi keinginan pelanggan. Berdasarkan hal tersebut artinya ukuran seberapa bagus tingkat layanan yang diberikan sesuai dengan ekspektasi pelanggan. Kkualitas merupakan suatu kondisi dinamis yang berhubungan dengan produk, jasa, manusia, proses, dan lingkungan yang memenuhi atau melebihi harapan.

Menurut Kotler (2012:284) menyebutkan lima dimensi Kualitas Pelayanan jasa yang harus dipenuhi yaitu : "Tangibles, Empathy, Reliability, Responsiveness, Assurance".

1. Tangibles (Bukti Fisik), yaitu penampilan fisik layanan perusahaan, seperti penampilan fasilitas fisik, peralatan, personel, kebersihan, kerapian dan media komunikasi.

2. Empathy, yaitu kesediaan karyawan dan pengusaha untuk lebih peduli memberikan perhatian secara pribadi kepada pelanggan.

3. Reliability (Kehandalan), yaitu kemampuan perusahaan untuk melaksanakan jasa yang dijanjikan dengan tepat dan terpercaya.

4. Responsiveness (Cepat tanggap), yaitu daya tanggap perusahaan dalam memberi layanan bagi pelanggan dan memberikan jasa dengan sigap dan cepat dalam melayani menangani transaksi dan penanganan keluhan pelanggan.

5. Assurance (Jaminan), yaitu kemampuan perusahaan memberi jaminan pelayanan yang merupakan pengetahuan dan kesopanan karyawan serta kemampuan mereka untuk menimbulkan kepercayaan dan keyakinan. 
Faktor yang dapat menyebabkan kualitas suatu jasa menjadi buruk, diantaranya adalah sebagai berikut :

1. Produk dan konsumsi yang terjadi secara simultan Salah satu karakteristik jasa yang paling penting adalah inseparability, yang artinya jasa diproduksi dan dikonsumsi pada saat yang bersamaan sehingga dalam memberikan jasa dibutuhkan kehadiran dan partisipasi pelanggan/nasabah. Akibatnya timbul masalah-masalah sehubungan dengan adanya interaksi antara produsen dan konsumen jasa, yang disebabkan karena tidak terampil dalam melayani pelanggan, penampilan yang tidak sopan, kurang ramah, cemberut, dan lain-lain.

2. Intensitas tenaga kerja yang tinggi. Keterlibatan karyawan secara intensif dalam penyampaian jasa dapat pula menimbulkan masalah kualitas, yaitu berupa tingginya variabilitas jasa yang dihasilkan. Faktor yang dapat mempengaruhi antara lain : upah rendah, pelatihan yang kurang memadai bahkan tidak sesuai denga kebutuhan organisasi

3. Dukungan terhadap pelanggan internal yang kurang memadai

4. Kesenjangan komunikasi: a) Perusahaan memberikan janji yang berlebihan, sehingga tidak dapat dipenuhi; b) Perusahaan tidak bisa selalu menyajikan informasi terbaru kepada pelanggan, misalnya berkaitan dengan prosedur atau aturan.

5. Memperlakukan pelanggan dengan cara yang sama Para pelanggan adalah manusia yang bersifat unik karena mereka memiliki perasaan dan emosi.

6. Perluasan dan pengembangan pelayanan secara berlebihan.

7. Visi bisnis jangka pendek (Tjiptono, 2011:175)

Kualitas pelayanan adalah: "The ability of a product to perform its functions", yang berarti kemampuan suatu produk dalam memberikan kinerja sesuai dengan fungsinya. Kualitas yang sangat baik akan membangun kepercayaan konsumen sehingga merupakan penunjang kepuasan konsumen (Kotler dan Amstrong, 2012:225).

\section{Metode Penelitian}

Penelitian ini merupakan deskriptif kuantitatif, yang digunakan untuk menganalisis pengaruh bauran pemasaran (product, price, promotion, place, people, physical evidance, process) dan kualitas pelayanan (Tangibles, Empathy, Reliability, Responsiveness, Assurance) terhadap keputusan pembelian pada PT Indomarco Pratama Denpasar Bali. Data untuk masingmasing variabel diperoleh dari hasil penyebaran kuisioner data yang diperoleh kemudian diberikan skor pada masing-masing jawaban responden dengan menggunakan skala likert.

Kerangka berpikir dalam penelitian ini adalah sebagai berikut : 


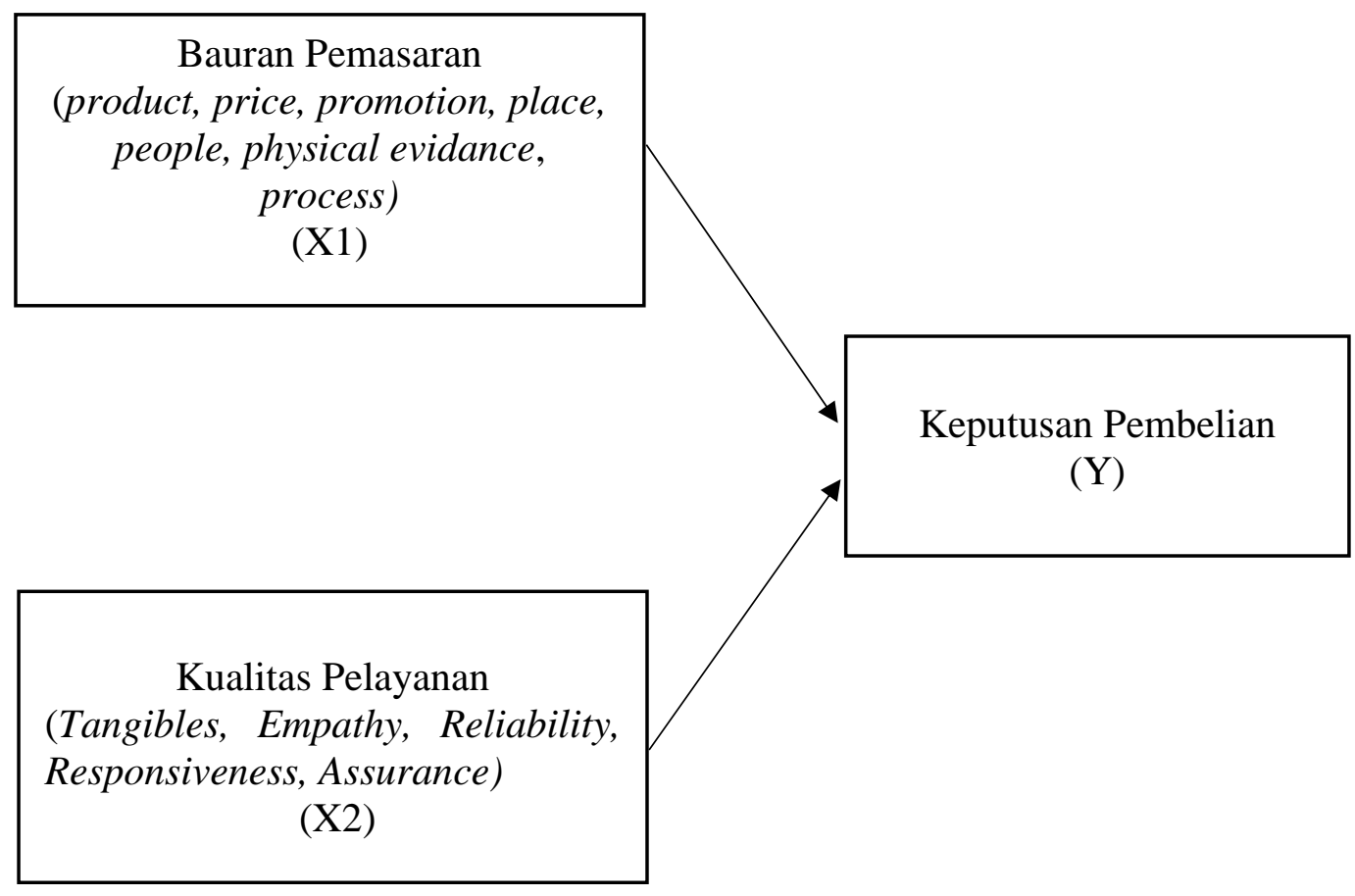

\section{Gambar 1. Kerangka Penelitian}

Populasi dalam penelitian ini adalah seluruh konsumen PT Indomarco Pratama Denpasar Bali. Pengambilan sampel penelitian menggunakan metode random sampling dengan jumlah sampel 100 orang. Instrumen penelitian yang digunakan terlebih dahulu diuji dengan uji validitas dan uji reliabilitas. Selanjutnya teknik analisis data yang digunakan dalam penelitian ini adalah uji asumsi klasik, analisis regresi linier berganda, uji t dan uji F.

\section{Hasil Penelitian dan Pembahasan}

Berdasarkan jenis kelamin, responden yang berjenis kelamin laki-laki adalah sebanyak 45 orang atau $45 \%$ dan berjenis kelamin perempuan sebanyak 65 orang atau $65 \%$. Konsumen perempuan memang lebih banyak dalam perusahaan ini karena kebutuhan belanja lebih banyak perempuan dibandingkan dengan laki-laki, atau bisa dikatakan kalaupun terdapat kebutuhan laki-laki maka perempuan yang membelanjakan. Sebagian besar responden berada pada rentang usia produktif yaitu 20-49 tahun, dengan lama bekerja sebagian besar pada rentang 3-5 tahun, yang menunjukkan bahwa sebagian besar konsumen memiliki pengalaman yang baik, dan sudah mengenal seluk beluk perusahaan dengan baik. Dari tingkat pendidikan, terbanyak merupakan tamatan SMA. Hal tersebut menunjukkan bahwa sebagian besar konsumen PT 
Indomarco Pratama Denpasar Bali mengenyam pendidikan menengah sehingga memiliki kompetensi dan skill penilaian yang baik terhadap perusahaan.

Berdasarkan hasil perhitungan dalam uji validitas dan uji reliabilitas, menunjukkan bahwa bahwa seluruh instrumen penelitian yang digunakan untuk mengukur masing-masing variabel yang digunakan adalah valid dan reliabel, karena memiliki koefisien korelasi lebih besar dari 0,4 dan koefisien reliabilitas (alpha cronbach) lebih besar dari 0,6. Dengan demikian variabel penelitian tersebut dapat digunakan untuk analisis statistik lebih lanjut. Berdasarkan pengujian asumsi klasik, model regresi bebas multikolineritas, tidak terjadi heteroskedastisitas, dan terdistribusi normal, sehingga model regresi dapat dilanjutkan kembali.

Analisis regresi linear berganda dilakukan untuk menganalisis pengaruh bauran pemasaran (X1), kualitas pelayanan (X2), terhadap keputusan pembelian (Y) dengan rumus persamaan regresi linier berganda sebagai berikut :

$$
\begin{aligned}
& Y=a+b X 1+b X 2 \\
& Y=54,920+0,434 X 1+0,342 X 2
\end{aligned}
$$

Dari persamaan diatas dapat diartikan beberapa penilaian sebagaimana berikut :

1. Dilihat dari nilai $\mathrm{a}=54,920, \mathrm{~b} 1=0,434, \mathrm{~b} 2=0,342$. Hal ini berarti apabila nilai dari bauran pemasaran (X1), kualitas pelayanan (X2), sama-sama nol (0), maka keputusan pembelian (Y) akan tetap ada sebesar 54,920.

2. Dilihat dari nilai $b 1=0,434$. Hal ini berarti apabila nilai dari bauran pemasaran $(\mathrm{X} 1)$ dinaikkan sebesar satuan maka akan mengakibatkan kenaikan dari nilai kepuasan kerja (Y) sebesar 0,434

3. Dilihat dari nilai b2 $=0,342$. Hal ini berarti apabila nilai kualitas pelayanan $(\mathrm{X} 2)$ dinaikkan satu satuan maka akan menyebabkan kenaikan dari nilai keputusan pembelian (Y) sebesar 0,342 .

4. Dilihat dari nilai $\mathrm{b} 1=0,434, \mathrm{~b} 2=0,342$, Hal ini berarti apabila nilai dari bauran pemasaran (X1), kualitas pelayanan (X2), sama-sama dinaikkan satu satuan maka akan menyebabkan kenaikan dari keputusan pembelian (Y) sebesar satu satuan pada konstanta 54,920.

Besarnya nilai koefisien korelasi berganda diperoleh hasil 0,850. Nilai dari koefisien korelasi berganda $(\mathrm{R})$ sebesar 0,850 menunjukkan bahwa hubungan secara simultan terhadap keputusan pembelian (Y) adalah sangat kuat, karena berada pada kisaran 0,800-1,000. Karena besarnya koefisien korelasi tersebut adalah positif maka arah hubungan secara simultan bauran pemasaran (X1), kualitas pelayanan (X2), terhadap keputusan pembelian (Y) adalah positif. Besarnya nilai dari koefisien korelasi berganda $(\mathrm{R})$ dalam penelitian ini yaitu 0,850 , maka nilai 
dari $\mathrm{R} 2$ adalah $0,856 . \mathrm{D}=\mathrm{R} 2 \times 100 \% \mathrm{D}=0,856 \times 100 \% \mathrm{D}=85,6 \%$ Berdasarkan hasil perhitungan tersebut diperoleh nilai dari koefisien determinasi sebesar 85,6\%. Hal ini berarti pengaruh secara simultan dari bauran pemasaran (X1), kualitas pelayanan (X2), terhadap keputusan pembelian (Y) pada PT Indomarco Pratama Denpasar Bali adalah sebesar 85,6\% dan sisanya 15,4\% dipengaruhi oleh variabel lain yang belum diteliti dalam penelitian ini.

\section{Pengaruh Bauran Pemasaran terhadap Keputusan Pembelian}

Berdasarkan hasil perhitungan diperoleh taraf signifikansi penelitian untuk variabel bauran pemasaran terhadap keputusan pembelian sebesar 0,002<0,05, sehingga $\mathrm{H} 0$ ditolak dan H1 diterima, dengan kata lain bauran pemasaran berpengaruh signifikan terhadap keputusan pembelian konsumen pada PT Indomarco Pratama Denpasar Bali. Hasil ini sekaligus menjawab hipotesis pertama penelitian ini. Hasil analisis data menunjukan bahwa bauran pemasaran memiliki pengaruh yang positif dan signifikan terhadap keputusan pembelian. Indikator terbesar yang memberikan pengaruh dalam penelitian ini adalah indikator product, price, dan promotion, sementara indikator lainnya place, people, physical evidance, process tidak terlalu berpengaruh. Hasil analisis memiliki makna bahwa semakin meningkatnya bauran pemasaran maka semakin meningkat pula keputusan pembelian konsumen. Dengan kata lain jika PT Indomarco Pratama Denpasar Bali mampu menerapkan bauran pemasaran secara maksimal maka keputusan pembelian yang dihasilkan akan meningkat maksimal.

\section{Pengaruh Kualitas Pelayanan terhadap Keputusan Pembelian}

Berdasarkan hasil perhitungan diperoleh taraf signifikansi penelitian untuk variabel kualitas pelayanan terhadap keputusan pembelian sebesar $0,003<0,05$, sehingga $\mathrm{H} 0$ ditolak dan H1 diterima, dengan kata lain kualitas pelayanan berpengaruh signifikan terhadap keputusan pembelian konsumen pada PT Indomarco Pratama Denpasar Bali. Hasil ini sekaligus menjawab hipotesis kedua penelitian ini. Hasil analisis data menunjukan bahwa kualitas pelayanan memiliki pengaruh yang positif dan signifikan terhadap keputusan pembelian. Indikator dalam kualitas pelayanan yang sangat berpengaruh dalam hal ini adalah Empathy, Reliability, Responsiveness, sementara Tangibles, Assurance tidak berpengaruh secara langsung. Hasil analisis memiliki makna bahwa semakin meningkatnya kualitas pelayanan maka semakin meningkat pula keputusan pembelian konsumen. Dengan kata lain jika PT Indomarco Pratama Denpasar Bali mampu menerapkan kualitas pelayanan secara maksimal maka keputusan pembelian yang dihasilkan akan meningkat maksimal. 


\section{Pengaruh Bauran Pemasaran dan Kualitas Pelayanan terhadap Keputusan Pembelian}

Berdasarkan hasil perhitungan diperoleh taraf signifikansi penelitian untuk variabel bauran pemasaran dan kualitas pelayanan terhadap keputusan pembelian sebesar $0,000<0,05$, sehingga $\mathrm{H} 0$ ditolak dan $\mathrm{H} 1$ diterima, dengan kata lain bauran pemasaran dan kualitas pelayanan berpengaruh signifikan terhadap keputusan pembelian pada PT Indomarco Pratama Denpasar Bali. Hasil ini sekaligus menjawab hipotesis ketiga penelitian ini. Hasil analisis data menunjukan bahwa bauran pemasaran dan kualitas pelayanan berpengaruh secara positif dan signifikan terhadap keputusan pembelian. Hasil analisis memiliki makna bahwa semakin meningkatnya bauran pemasaran dan kualitas pelayanan maka semakin meningkat pula keputusan pembelian. Dengan kata lain jika pihak PT Indomarco Pratama Denpasar Bali mampu meningkatkan bauran pemasaran dan kualitas pelayanan dengan maksimal maka keputusan pembelian yang dihasilkan juga akan meningkat dengan maksimal.

\section{Simpulan}

Bauran pemasaran berpengaruh secara parsial terhadap keputusan pembelian konsumen pada PT Indomarco Pratama Denpasar Bali sebesar 0,002<0,05, dengan indikator product, price, dan promotion yang dominan, kemudian menyusul indikator lainnya place, people, physical evidance, process. Kualitas pelayanan berpengaruh secara parsial terhadap keputusan pembelian konsumen pada PT Indomarco Pratama Denpasar Bali sebesar sebesar 0,003<0,05, dengan indikator Empathy, Reliability, Responsiveness yang dominan, kemudian indikator tangibles, assurance menyusul. Secara simultant bauran pemasaran dan kualitas pelayanan bepengaruh terhadap keputusan pembelian sebesar 0,000<0,05. Hasil ini sekaligus menjawab hipotesis ketiga penelitian ini. Hasil analisis data menunjukan bahwa bauran pemasaran dan kualitas pelayanan berpengaruh secara positif dan signifikan terhadap keputusan pembelian. Hasil analisis memiliki makna bahwa semakin meningkatnya bauran pemasaran dan kualitas pelayanan maka semakin meningkat pula keputusan pembelian pada PT Indomarco Pratama Denpasar Bali.

\section{Daftar Pustaka}

Alfiani, Lia Dkk. 2014. Pengaruh Bauran Pemasaran Terhadap Keputusan Pembelian Produk Multilevel Marketing (Studi Pada PT. Sinar Nusa Indonesia Di Kota Semarang). Diponegoro Journal Of Social And Politic.

Asosiasi Pengusaha Ritel Indonesia. 2020. www.aprindo.org. diakses 3 Maret 2020.

Hasrina. 2017. Pengaruh Bauran Pemasaran Terhadap Keputusan Pembelian Mobil Toyota Yaris Pada PT. Hadji Kalla Cabang Urip Sumoharjo Di Kota Makassar. Skripsi Universitas Negeri Makassar.

Keegan, Warren J, Sandra Moriarty, Tom Duncan. 1995. Marketing. New jersey : Prentice Hall. 
Kotler, Philip dan Armstrong, Gary. 2012. Principles of Marketing. New Jersey : Prentice Hall. Kotler, Philip. 2000. Prinsip - Prinsip Pemasaran Manajemen. Jakarta : Prenhalindo.

Manap, Abdul. 2016. Revolusi Manajemen Pemasaran. Jakarta : Mitra Wacana Media.

Malau, Harman. 2016. Manajemen Pemasaran: Teori dan Aplikasi Pemasaran Era Tradisional Sampai Era Modernisasi Global. Bandung : Alfabeta.

Payne, Adrian . 2000. Pemasaran Jasa (The Essence of Service Marketing). Yogyakarta : Andi. Offset.

Pertiwi, Marina Intan Dkk. 2016. Pengaruh Bauran Pemasaran Terhadap Keputusan Pembelian (Survei pada Konsumen Baker's King Donuts \& Coffee di MX Mall Malang). Jurnal Administrasi Bisnis (JAB) Vol. 37 No. 1 Agustus 2016.

Sangadji, Etta Mamang dan Sopiah. 2013. Perilaku Konsumen. Yogyakarta : CV Andi Offset. Sunyoto, Danang. 2014. Konsep Dasar Riset Pemasaran \& Perilaku Konsumen, Cet. 1. Yogyakarta : CAPS.

Tjiptono, Fandy. 2008. Strategi Pemasaran. Edisi 3. Yogyakarta : Andi Offset.

Tjiptono, Fandy. 2014. Pemasaran Jasa (Prinsip, Penerapan, Penelitian). Yogyakarta. Andi Offset.

Wiratno, Dwi Haryono. 1998. Praktik Akuntansi. Yogyakarta : AA YKPN.

Yamit, Zulian. 2005. Manajemen Kualitas Produk dan Jasa. Edisi Pertama, Cetakan Keempat. Yogyakarta : Penerbit Ekonisia.

Zeithaml,Valarie A and Bitner. 2000. Service Marketing 2nd edition : Integrating Customer Focus. New York : McGraw-Hill Inc. 